\title{
A cut-marked and fractured Mesolithic human bone from Kent's Cavern, Devon, UK
}

\author{
Rick J. Schulting*, University of Oxford \\ Silvia M. Bello, The Natural History Museum, London \\ Barry Chandler, Torquay Museum \\ Thomas F.G. Higham, University of Oxford
}

Revised paper submitted to the International Journal of Osteoarchaeology, May 2012

Not for citation without written permission from corresponding author

*Corresponding author: rick.schulting@arch.ox.ac.uk

Funding for radiocarbon dating: NERC's ORADS programme NF/2009/2/16; Leverhulme Trust Research Grant F/08 735/E

Key words: cannibalism, anthropophagy, Palaeolithic, Gough’s Cave, Europe

Running title: Kent’s Cavern Mesolithic cut-marked ulna 


\begin{abstract}
An isolated adult human ulna fragment recovered from the 'black mould' layer of Kent's Cavern by William Pengelly in 1866 exhibits a series of stone-tool cut-marks. The specimen has been directly $A M S{ }^{14} C$-dated to 7314-7075 cal BC (OxA-20588: $\left.8185 \pm 38 \mathrm{BP}\right)$, and may be from the same individual as a maxilla fragment dated to the same period. The cut-marks are located on the olecranon process, in a position indicative of dismemberment, while the fracture characteristics of the bone furthermore suggest peri-mortem breakage, typical of butchery for the extraction of marrow. We here present and discuss the specimen, and consider both ritual mortuary treatment and anthropophagy as possible explanations. While it is difficult to interpret a single element in isolation, the latter scenario seems to be better supported, and is not without parallel in prehistoric Europe, as indicated by a review of the available literature.
\end{abstract}

Located near Torquay on the Devon coast of southwest England, Kent's Cavern (Figure 1), is best known for yielding the earliest anatomically modern human bone currently identified in Britain (Higham et al., 2011; Jacobi and Higham, 2010), and for its Quaternary sedimentary record and its large Pleistocene faunal assemblage, representing multiple glacial and interglacial periods (Bocherens et al., 1995; Campbell, 1977; Campbell and Sampson 1971; Garrod, 1926; Keen 1998; Lundberg and McFarlane, 2007; McFarlane and Lundberg, 2005). In addition to the Palaeolithic human maxilla, the cave has also produced Mesolithic human remains, with a maxilla dated to 7308-6698 cal BC (OxA-1786: $8070 \pm 90 \mathrm{BP}$, Hedges et al., 1989), and it is this period that forms the focus of this paper. Small numbers of fragmentary human remains have been and continue to be identified amongst the large faunal assemblage from Kent's Cavern. Among the most recent discoveries is that of a proximal adult human ulna bearing a series of fine cut-marks on its proximal end. An initial examination by hand lens indicated that the cut-marks were ancient, and likely to have been made by a stone tool. This provided the impetus for a more in-depth study, the results of which are presented here (expanding on a brief earlier report in Chandler et al., 2009). We describe the element and the results of detailed visual examination, and present an AMS determination placing it within the early part of the British Late Mesolithic. We also present a new result for the previously dated maxilla, indicating that the two elements are contemporary in radiocarbon terms and may refer to the same individual. Interpretation of the 
cut-marked ulna in the wider context of Mesolithic Europe considers two main - though not mutually exclusive - possibilities: ritual dismemberment and anthropophagy/cannibalism.

\section{THE SITE}

The extensive cave system of Kent's Cavern, Torquay, Devon $\left(50.4670^{\circ} \mathrm{N}, 3.5034^{\circ} \mathrm{W}\right.$; 60m OD) was created by dissolution of the Middle-Upper Devonian Limestone that formed in a warm shallow sea around 390-360 million years ago (Lundberg and McFarlane, 2008). The karst system consists of two parallel sets of chambers linked by interconnecting chambers or fissures, in total extending over approximately one kilometre. It records continuous, repeated sedimentation events, punctuated by frost shattering that track all the major climatic cycles over 500,000 years, possibly making the cave unique in a European-wide context (Lundberg and McFarlane, 2007). The cave currently has two entrances situated about 15 metres apart. The North Entrance leads onto the Vestibule, and Sloping Chamber, while the South Entrance leads to the Great Chamber, connecting through the Passage of Urns to the Sloping Chamber and Vestibule (Figure 2). These two entrances would have provided access to the cave throughout the Holocene, as is evident in the archaeology of the uppermost sedimentary layer that filled the most accessible areas of the cave, with many different prehistoric and historic periods represented.

\section{William Pengelly's excavation of the 'black mould'}

Earlier visits aside, Kent's Hole (as it was originally known) has been the subject of scientific investigation since Northmore’s search for a 'Mithratic Cavern' brought him to the cave in 1824 (Pengelly, 1868; 1885). Father John MacEnery first recorded the true nature of the deposits during intermittent excavations between 1825 and 1829, from which he recovered flint tools in situ below the stalagmite on the cave floor (MacEnery, 1859), fueling the vigorous debate between religious and secular scientists on the 'antiquity of Man'. Indeed, many of these debates came to be held in the Torquay Museum, founded in 1845. For the purposes of this paper, however, the excavations of principal importance are those conducted by William Pengelly between September 1864 and August 1879. Pengelly applied to Kent's Cavern the excavation techniques he first trialed at Brixham Cave between 1858-59. The task at Kent's was considerably more complex, as the sheer size of the cavern and the width of the chambers required an excavation system that was truly three-dimensional in its scope (McFarlane and 
Lundberg, 2005). His solution to this problem would become a cornerstone of modern scientific archaeological investigation, with its first application to the uppermost 'black mould' layer of Kent’s Cavern (Warren and Rose, 1994). Writing in 1865, Pengelly’s manuscript diaries record his excavation technique.

A line, termed the "Datum Line" or "Datum" was stretched horizontally from a fixed point on the external face of the masonry at the Entrance to another point at the back of the Great Chamber, and intersecting at right angles the section which had been cut as described above. The direction of this line, carefully ascertained by compass was W. $5^{\circ} \mathrm{N}$. magnetic: Lines one foot apart are to be drawn at right angles to the Datum line, and therefore parallel to one another, across the Great Chamber so as to divide its surface into belts, termed "foot-parallels" or "parallels". In each Parallel the Black Mould between the large masses of Limestone is to be carefully examined in situ, and then taken to the Entrance of the Cavern for re-examination in full daylight. (Pengelly, 1863-1868, 10)

Pengelly believed the sediments of the 'Black Mould' represented some 1500 to 2000 years of time. The exact composition of this layer has never been determined, but it certainly contained charcoal, ash, decayed organic material, leaf fall, shells, animal and human bone and a range of artifacts principally spanning the Mesolithic to the Romano-British and medieval periods though none of the directly dated fauna has yet yielded a Mesolithic result. The black mould formed a layer 3-12 inches (0.1-0.3m) in thickness lying between and beneath limestone blocks (Pengelly, 1866). The excavation technique described above was employed slightly differently to the black mould and granular stalagmite than the lower strata of the cave. In the cave earth for example, a prism of sediment 1 foot by 1 foot by 1 yard was given an individual context number, but in areas of the black mould groups of parallels were removed and given a single context number. During Pengelly's sixteen seasons of excavation he would remove this layer in its entirety, leaving only isolated fragments embedded in the walls of the Great Chamber (C. Proctor, pers. comm.). Between Tuesday $25^{\text {th }}$ and Friday $28^{\text {th }}$ September 1866, workmen in the Sloping Chamber removed the $34^{\text {th }}$ to $46^{\text {th }}$ parallels of black mould (an area of approximately $4.2 \mathrm{~m}^{2}$ by up to $0.3 \mathrm{~m}$ depth). Items found included charcoal, pebbles, a whetstone, pieces of slate, a perforated stone and various shells (Pengelly 1866). Unrecognized by the workmen among 
several hundred pieces of bone were human remains including the fragmentary human ulna that is the focus of this paper.

\section{THE ULNA}

The proximal third of an adult right ulna (Torquay Museum A6473) was found in Pengelly's excavations at Kent's Cavern (Pengelly no. 1774, 28/09/1866), and, as noted above, can be attributed to the 'black mould' in the Sloping Chamber near the front of the cave system. It was recognized by one of the authors $(\mathrm{BC})$ amongst the large faunal assemblage from the site that is still being documented and analysed. The element is very well-preserved, with sound cortical surfaces lacking any weathering damage, and is of an average size and robusticity. Its surviving length is $94.8 \mathrm{~mm}$, with a maximum medio-lateral width of the olecranon process of $21.5 \mathrm{~mm}$ (Figure 3). The fragment is insufficiently complete to determine sex. The impetus for the present investigation came from the presence of a series of fine cut-marks observed on the proximal end (Figure 4).

Detailed examination of the interior surfaces of the cut-marks is made difficult by the liberal application of a consolidant, seen on much of the Kent's Cavern bone assemblage. Thus, the use of scanning electron microscopy is not possible at present, and the element was initially analyzed using a hand lens and binocular microscope (Chandler et al., 2009). The more detailed analysis presented here uses an Alicona InfiniteFocus optical surface measurement system (Bello and Soligo, 2008; Bello et al., 2009) to produce detailed three-dimensional models of the humanly modified surfaces (lens 2.5x, vertical resolution $9.0 \mu \mathrm{m}$ and lateral resolution $1.65 \mu \mathrm{m}$; lens 5x, vertical resolution $999 \mathrm{~nm}$ and lateral resolution $1.49 \mu \mathrm{m}$ ). Three clusters of slicing cut-marks are present on the posterior border of the proximal end of the ulna, all transversally oriented to the bone’s main axis. All are well-patinated, with some continuing under adhering sediment; therefore, none can be attributed to excavation or post-excavation instrument damage. Their micromorphological features are consistent with incisions made by a stone tool, being relatively wide compared to cuts made by a metal edge, and showing clear examples of double parallel lines (Andrews and Cook, 1985; Behrensmeyer et al., 1986; Bello and Soligo, 2008; Boulestin, 1999; Domínguez-Rodrigo et al., 2009; Greenfield, 1999; Shipman, 1981; Shipman and Rose, 1983; White, 1992). 
Beginning at the proximal end, the first cluster consists of four sub-parallel cut-marks located just below the olecranon process. They are generally short (about 3-4 mm), large (average width at surface level of $176 \mu \mathrm{m}$ ) and with an average depth (taken at the mid-point of each cut) of about $40 \mu \mathrm{m}$. Their V-shape cross-sectional profiles suggest that they were made by a stone tool held almost perpendicular to the bone surface, the angle of tool impact (Bello and Soligo, 2008) having an average inclination towards the bone surface of about $82^{\circ}$ (Figure 5). A second cluster of four cut-marks is located about $0.5 \mathrm{~cm}$ distal to the first, but towards the medial part of the ulna. These cut-marks are also short (2-3 mm) and sub-parallel to each other, but slightly narrower (average width at surface level of $136 \mu \mathrm{m}$ ) and shallower (average depth taken at the mid-point of each cut of $29 \mu \mathrm{m}$ ) than those of the first group; two are extremely shallow, less than $20 \mu \mathrm{m}$, and are better classed as superficial scratches rather than slicing cut-marks. This second cluster of four cut-marks all present a neat V-shape cross-section, the angle of tool impact being almost perpendicular to the bone surface (with an average inclination of ca. $86^{\circ}$; Bello and Soligo, 2008). The final cluster is located about $14 \mathrm{~mm}$ distal to the second cluster at the mid point of the olecranon process. It consists of two longer $(\sim 6 \mathrm{~mm})$ cuts with micro-morphological characteristics very close to those observed for the cut-marks forming the first cluster: width about $200 \mu \mathrm{m}$, depth $43 \mu \mathrm{m}$ and average inclination of the tool being about $82^{\circ}$. These cut-marks are partially covered by adhering $\mathrm{CaCO}_{3}$ sediment. The cross-sectional profiles of all analysed cuts indicate that they were made with the tool held almost perpendicular to the bone surface, suggesting a cutting rather than a filleting action (Bello et al., 2009; 2011). The microscopic identification of Hertzian cones along these cut-marks would indicate that that they all have the same direction (Bromage and Boyde, 1984) with a starting point on the lateral aspect of the olecranon process. Considering the directionality and the evaluated inclination of the angle of the tool impact, it is likely that the tool was used by a right-handed person (Bermúdez de Castro et al., 1988; Bromage and Boyd, 1984; Pickering and Hensley-Marschand, 2008).

The cut-marks are all found on the flat, elongated triangle of bone forming the posterior of the olecranon. While various muscle groups attach to the very top of the process, and to either side, the triangle itself is covered by a subcutaneous bursa, a small sac composed of fibrous tissue and filled with synovial fluid, providing a cushion between the bone and the muscles surrounding a 
joint, in this case the elbow (Gray, 1977 [1901]). Presumably, the cuts were made to remove superficial tissues and to cut through the bursa to facilitate separation of the forearm.

In addition to the cut-marks described above, a notch on the ulna's medial surface, just below the coronoid process, exhibits all of the characteristics of an impact point made on fresh bone, with patinated internal bevelling forming part of a percussion cone (Figure 6) (Boulestin, 1999; Blumenschine and Selvaggio, 1988; Knüsel and Outram 2006; Pickering and Egeland, 2006; Villa and Mahieu, 1991; Turner and Turner, 1999; White, 1992). As a result of this impact, the ulna as a whole is fractured lengthwise from the trochlear notch, continuing down the anterior surface before terminating in a sharp point (Figure 7). The fracture is spiral, with smooth surfaces, both features being strongly suggestive of peri-mortem breakage (cf. Knüsel, 2005; Knüsel and Outram, 2006; Outram, 2002; Villa and Mahieu, 1991; Wheatley, 2007). Taken together, the impact point and fracture margins indicate that the ulna was intentionally struck and split while still fresh, either with a heavy stone tool or simply an unmodified cobble. While there is no direct relationship between the cut-marks and the fracture (e.g., no cut-marks terminate into a fracture edge), it is highly probable that the forearm was first removed by cutting with a fine stone blade through the main muscles, tendons and other tissues attaching it to the humerus, and then struck with a heavier stone implement to split it.

With confirmation that the cut-marks were caused by a stone tool, a prehistoric age for the ulna would be expected. But given the lack of any reliable stratigraphy or archaeological associations, and the wide range of dating evidence for human remains in Kent's Cavern (Chandler et al., 2009; Hedges et al., 1989; 1991; 1996; Jacobi et al., 2006; Silvester, 1986; Tuross, 2003), direct radiocarbon dating was the only means of determining the element's age more precisely. We turn to this now.

\section{RADIOCARBON DATING AND STABLE ISOTOPE ANALYSIS}

A small sample of bone was removed from the medullary cavity of the Kent's Cavern ulna (A6473). Because of the liberal use of a consolidant (probably PVA) on much of the assemblage, including the ulna, the area was first mechanically cleaned. Following this, the bone was sampled using a tungsten carbide drill, removing bone powder weighing $360 \mathrm{mg}$. The powder was treated 
with sequential solvents, including methanol, designed to mobilise and thereby remove any consolidants. Bone collagen was then extracted by decalcification with $0.5 \mathrm{M} \mathrm{HCl}$, followed by an 0.1M NaOH wash, and a re-acidification using 0.5M HCl. Between each step a distilled water rinse was applied. The collagen was gelatinised in weakly acidic $\mathrm{pH} 3$ water at $75^{\circ} \mathrm{C}$ in an incubator for 20 hours. The supernatant was recovered using an EziFilter ${ }^{\mathrm{TM}}$. The gelatin was then ultrafiltered using a Vivaspin $^{\mathrm{TM}} 30$ kD MWCO ultrafilter (see Bronk Ramsey et al., 2004a; Higham et al., 2006) and the $>30 \mathrm{kD}$ fraction freeze-dried. We extracted $25 \mathrm{mg}$ from the bone sampled, a yield of $7 \%$ by weight, indicating that the bone is well-preserved. The ultrafiltered gelatin was then combusted, graphitised and AMS dated after Bronk Ramsey et al. (2004b). We feel confident that the contaminant was removed using these methods, and that the estimate discussed below reflects the true age of the specimen.

The sample provided an ${ }^{14} \mathrm{C}$ AMS determination of $8185 \pm 38$ BP (OxA-20588: 7314-7075 cal $\mathrm{BC}$ at $95 \%$ confidence), placing it within the early part of the British Late Mesolithic. The $\delta^{13} \mathrm{C}$ value of $-19.7 \%$ indicates little or no appreciable consumption of marine protein in the diet of this individual, and so no correction for a marine reservoir effect is necessary. The slight elevation (of ca. 1\%o) compared to a purely terrestrial endpoint appears to be typical of early Holocene human and faunal remains in Britain, even in inland locations such as Aveline's Hole, Somerset (Schulting, 2005; see also Richards and Hedges, 2000). While Kent's Cavern is currently less than 500m from the coast, sea levels would have been some $20 \mathrm{~m}$ lower at ca. 8000 ${ }^{14} \mathrm{C}$ years BP (Heyworth and Kidson, 1982), so that the coast would have been a few kilometres distant. Nevertheless, the absence of clear isotopic evidence for the consumption of marine foods is surprising, given the findings from this period at Caldey Island in south Wales (Schulting and Richards, 2002). The $\delta^{15} \mathrm{~N}$ value of $10.2 \%$ is moderately high, but not sufficiently so to suggest a reliance on freshwater fish (e.g., G. Cook et al., 2001), nor would this be expected to be a major resource in this part of Devon (i.e., there are no major river or lake systems in the immediate vicinity). Both isotope values are averages of measurements run in triplicate on a SerCon mass spectrometer. The C:N ratio of 3.4 is within the accepted range for in vivo collagen (DeNiro, 1985). 
A list of the directly dated human elements from Kent's Cavern is provided in Table 1 . These include a number of specimens from the 'black mould' in the Sloping Chamber near the entrance, in which the ulna was found, though most of these have been dated to Neolithic and later periods. Interestingly, the new determination from Kent's Cavern falls very close to the previously reported result of $8070 \pm 90 \mathrm{BP}(\mathrm{OxA}-1786$ : 7308-6698 cal BC) on a human maxilla (Hedges et al. 1989). In order to confirm their near-contemporaneity, a new measurement was made on this maxilla, in the light of advances in pre-treatment and the higher precision now available (Brock et al., 2007; 2010; Bronk Ramsey et al., 2004b). The new result of $8270 \pm 45$ BP (OxA-23812: 7478-7145 cal BC) is closer to the date for the ulna, and differs significantly from the previous determination on the maxilla $\left(\chi^{2}, \mathrm{~T}=3.9(5 \%, 3.8)\right.$ (Ward and Wilson, 1978)). OxA-1786 is therefore now replaced by OxA-23812; as a heuristic exercise, the latter and OxA-20588 on the ulna may be combined to $8221 \pm 30 \mathrm{BP}\left(7344-7083\right.$ cal BC; $\chi^{2}, \mathrm{~T}=2.1(5 \%, 3.8)$. It is thus conceivable that they belong to the same individual, though the two specimens demonstrate very different appearances, with the maxilla fragment coloured white and partially covered in a stalagmite concretion (Figure 8). Nevertheless, both are recorded as deriving from the 'black mould' layer near the entrance of the cave system (the ulna from the Sloping Chamber, and the maxilla from the Vestibule - artefacts and AMS-dated fauna both confirm a Late Upper Palaeolithic presence in the black mould layer, as well as later material (Hedges et al., 1991; 1996)). Most recently, the former includes a determination of $12308 \pm 39$ BP (12922-12046 cal BC, from combined repeat results on the same specimen: OxA-23816, $12265 \pm 55$ BP and OxA23817, $12350 \pm 55$ BP) on a red deer humerus displaying a spiral fracture (Figure 9).

The $\delta^{13} \mathrm{C}$ and $\delta^{15} \mathrm{~N}$ values for the human maxilla, -19.3\%o and 10.2\%o, respectively, do not differ significantly from those obtained on the ulna, and so are not inconsistent with their attribution to the same individual. The absence of any other dated Mesolithic human remains from the site suggests that, unlike Aveline’s Hole in Somerset (Schulting, 2005), Kent’s Cavern was not a major burial site for the period. Other determinations on isolated human bones from the black mould of the Sloping Chamber refer to the Early Neolithic (ca. 3800 cal BC), Early and Late Bronze Age (ca. 1800 and 1200 cal BC, respectively), Anglo-Saxon (ca. cal AD 400-600) and medieval period (ca. cal AD 1300-1400) (Table 1). 


\section{DISCUSSION}

Human remains dating to the Mesolithic are comparatively rare in Britain (Meiklejohn et al., 2011), making the placement of the Kent's Cavern ulna in this period of some interest in its own right, though of course this is severely limited by its being a single element, partial at that, without any contextual associations. The closest find in terms of age, aside from the abovementioned maxilla, is an isolated clavicle fragment from Oreston Cave, Devon (Chamberlain, 1996). A much larger assemblage of Mesolithic human remains comes from Aveline's Hole, Somerset, with early reports of as many as 50 or more skeletons, of which fragments of at least 21 individuals survive (Schulting, 2005). These have been dated to ca. 8300 cal BC (Marshall and van der Plicht, 2005). When taken together with Mesolithic human remains from caves and rockshelters in south Wales (Schulting and Richards, 2002; Schulting, 2009), south-west Britain clearly emerges as a comparatively rich area for human skeletal remains of this period (see summary in Meiklejohn et al., 2011). This is presumably due in large part to a combination of the presence of suitable burial contexts (caves), good preservation conditions (the band of limestone running through the area), and a long history of research.

Despite being limited to a single element, the Kent's Cavern ulna takes on considerably more importance through the presence of cut-marks and peri-mortem fracturing, both of which, while far from unknown, are relatively rare in British, and indeed European, prehistory (none have been identified in the Mesolithic sites mentioned above). It is their co-occurrence on the ulna that is particularly interesting, and may shed some light on the circumstances involved.

It is unusual to find evidence of peri-mortem breakage to limb bones, as opposed to peri-mortem cranial fractures, usually interpreted within a context of interpersonal violence (e.g., Schulting and Wysocki, 2005). Aside from issues of identification (see Knüsel, 2005; Knüsel and Outram, 2006; Villa and Mahieu, 1991), interpretation of post-cranial peri-mortem fracturing is fraught with difficulties when dealing with human remains, not least because it raises the highly contentious issue of anthropophagy. The criteria for acceptance become that much more stringent, compared with that for the butchery of animals (Turner and Turner, 1999; White, 1992). There is no convincing evidence for burning on the Kent's Cavern ulna, nor of so-called 'pot polish' (abrading of the broken ends of long bones though contact with unglazed pottery 
during cooking) on the fracture margins, though of course both these criteria depend on the treatment of the element after breakage (and, in the latter case, on the presence of pottery, which did not form part of the material culture repertoire of the British Mesolithic). Cut-marks can be, and usually are, interpreted as post-mortem ritual treatment of the dead (e.g., Auboire, 1991; Wakely in Evans and Hodder, 2006, 147-148; Cauwe, 1998; McKinley, 2008; Murphy, 2003; Smith and Brickley, 2004; Smits and van der Plicht, 2009; Toussaint, 2011). Peri-mortem fractures could conceivably occur by accident, such as by a rockfall. However, the coincidence of cutmarks and peri-mortem breakage arguably provide a context more suggestive of processing of the corpse for consumption (cf. Villa et al., 1986, 431). While the main alternative, of postmortem ritual defleshing, provides an equally valid (indeed, perhaps more so) interpretation for the cut-marks, it is less clear why intentional splitting of the bone should follow in this scenario. It is not inconceivable that ritual processing would take this further step; indeed, fracturing of human bone for the removal of marrow - without consumption - as part of the funerary rite has been reported from Aboriginal Australia (Pickering, 1989; 1999). Whether such an interpretation can be applied in the European context is another question, one to which we return below. Although it is still comparatively rare, there is far more evidence for cut-marks relating simply to disarticulation and/or defleshing (see sources cited above). Furthermore, the former practice need not necessarily leave traces on the bones, particularly if the body were already fully or partly decomposed and could be disarticulated with minimal need for cutting. La Chaussée-Tirancourt (Somme), northeast France, provides a clear example of a secondary burial rite dating to the Early Mesolithic, with the long bones laid side by side in a pit in a bundle-like arrangement, surmounted by the skull (Ducrocq et al., 1996).

There are wider British and European comparanda upon which to draw for the co-occurrence of cut-marks and peri-mortem fracturing. The first point of comparison with the Kent's Cavern ulna is the human bone assemblage from Gough's Cave, Somerset, some 110 km northeast of Kent's Cavern (Figure 1). Although it is considerably earlier, dating to the Late Upper Palaeolithic, 14,700 cal BP (Jacobi and Higham, 2009), this period shares with the Kent's Cavern find both a hunter-gatherer way of life and general geographical proximity. Cut-marks are present on a number of adult and subadult elements at Gough's Cave, both cranial and post-cranial. The nature of the assemblage has been debated, with Cook $(1986 ; 1991)$ accepting very few of the 
cut-marks and preferring to suspend judgment regarding their interpretation. In contrast, Andrews and Fernández-Jalvo have presented a case for cannibalism, pointing to the similar treatment of the human and faunal remains, to the occurrence of peri-mortem fractures as well as cut-marks, and to the presence of what they interpret as human tooth-marks (Andrews and Fernández-Jalvo, 2003; Fernández-Jalvo and Andrews, 2011). The most recent study follows in this vein, highlighting the frequency of cut-marks and intentional fracturing on the crania, suggesting a fairly elaborate and specific post-mortem treatment intended to produce something akin to 'skull cups' (Bello et al., 2011), though whether and, if so, how they were actually used is unknown. Of more direct relevance here is the occurrence of cut-marks on the postcranial remains from Gough's Cave, including two ulnae. While their location does not match those on the Kent's Cavern ulna, percussion pits can be observed in a similar anatomical location on the same two specimens with cut-marks (Figures 10 and 11).

In a wider northwest European Mesolithic context, there are a number of sites where cut-marks have been identified on human remains. For the most part, the interpretation of these has tended to favour ritual defleshing and dismemberment, as a means of hastening the process of transformation from a fleshed corpse to disarticulated skeletal remains. The underlying rationale for this is, in turn, typically viewed as speeding the process of joining the 'ancestors', however these are to be defined (see Whitley, 2002), a notion and practice that is more often thought of in conjunction with Neolithic farmers (Barrett, 1994; Thomas, 1999). There are, however, two examples of northwest European Mesolithic sites where the issue of cannibalism has been raised: Dyrholmen in Denmark (Degerbøhl, 1942), and La Grotte des Perrats à Agris in France (Boulestin, 1999). Little can be said about Dyrholmen, as there has been no re-analysis of the skeletal assemblage, and many of the criteria for the identification of cannibalism - or even perimortem fracture - were undeveloped at the time. La Grotte des Perrats à Agris differs in being a more recent excavation and analysis. The site includes a relatively large commingled assemblage of human and animal bone, dated to ca. $7000 \mathrm{cal}$ BC. Both the faunal and human remains present evidence of burning together with cut-marks and peri-mortem fracturing (Boulestin, 1999; Boulestin and Gomez de Soto, 1995). The human remains represent at least eight individuals, including five adults and three children. They show cut-marks and peri-mortem fracturing to both crania and post-crania, with the former including injuries interpreted as being the probable cause 
of death for some individuals. Cut-marks and percussion marks occur on a number of ulnae (Boulestin, 1999, plates XXXIV-XXXVI), with one of the latter being in a similar position to that seen on the Kent's Cavern specimen (ibid., fig. 61).

Casting the chronological net slightly wider, there are also cases to be made for the Neolithic period. Dating to ca. 5200-5000 cal BC, the Early Neolithic site of La Grotte du Gardon (Ain), France, held the very partial remains of a man, a woman and a child, found mixed together with faunal remains, with both showing traces of burning, cut-marks and intentional fracturing (Chaix et al., 1991). Similar evidence has been found at Fontbrégoua (Salernes), southern France (Villa, 1992; Villa et al., 1986). While Boulestin (1999; see also Boulestin and Gomez de Soto, 1995) raises some reservations concerning the details at this site, he does still concur that cannibalism likely occurred there, in a ritual context. More controversial claims for mass cannibalism have been made for the Early Neolithic (ca. 5000 cal BC) enclosure of Herxheim, Germany (Boulestin et al., 2009), with Orschiedt and Haidle (2007; 2012) arguing that the fractured and cut-marked remains represent post-mortem ritual treatment of the dead. Early suggestions of cannibalism made for the Late Neolithic Pitted Ware Culture site of Jettböle (3370-2840 cal BC), Åland, Sweden, have, despite initial skepticism, been supported in a recent re-analysis (Nuñez and Líden, 1997). As at La Grotte des Perrats à Agris, a strong case can be made at Jettböle, since the human and animal remains show similar treatment - bearing traces of burning, cut-marks, and peri-mortem fracturing - and were found scattered together in a midden deposit (cf. Turner and Turner, 1999). While nominally Neolithic, the subsistence economy of Pitted Ware groups was strongly based on seal hunting, with minimal contribution from domestic plants and animals, so that they have more in common with earlier Mesolithic lifestyles than with Neolithic farmers present across much of Europe at this time, including elsewhere in southern Scandinavia (Nuñez and Líden, 1997).

A key point in a number of the above studies is the similar treatment of human and animal bone, both in terms of traces of butchery, and of final deposition. It is this similar treatment and seemingly casual disposal of human and animal remains that present a more convincing case for anthropophagy, and would seem to weigh against a funerary rite that involved both disarticulation and splitting of the bone, as has been raised as an alternative interpretation by 
Pickering (1989) based on the occurrence of this practice in Aboriginal Australia. Unfortunately, the nature of the Kent's Cavern material precludes a direct comparison of the human and animal remains.

The point of the above examples is to demonstrate that, while evidence for anthropophagy in the prehistoric European archaeological record is rare, it is not entirely absent (nor do the above examples constitute a comprehensive survey). Thus, the interpretation of the ulna from Kent's Cavern in this context would not be without precedent. Indeed, given the stigma attached to cannibalism, and the reluctance of many researchers to entertain it without overwhelming proof (e.g., Arens, 1979; Bahn, 1990) - in marked contrast to the antiquarian enthusiasm for prehistoric cannibalism, commented upon for example by Brothwell (1961) - it may be suggested that the practice was rather more widespread than the current evidence would suggest (cf. Taylor, 2003). But even if accepted, this in itself says little about the all-important reasons behind it. The fact that evidence for the butchery of human remains is not more widespread in prehistoric Britain (and Europe in general) indicates that such occurrences were rare and were not part of typical funerary behaviour, and certainly not a normal aspect of subsistence, as recently suggested for Lower Palaeolithic Europe by Carbonell et al. (2010). This would seem to weigh against an interpretation of ritual cannibalism as a normative practice, and suggests instead a context of transgression. Starvation cannibalism can occur in extremis, and presents one possibility. One could also envisage a scenario of punishment for the breaking of social taboos, or an insult dealt to an enemy. Conversely, anthropopaghy can also occur as a mark of respect for the dead, usually one's own relatives (i.e., endo- versus exo-cannibalism). Evidence for all of these practices and others can be found in the ethnographic records of the band and tribal-level societies that provide the best, even if far from perfect, analogues for earlier prehistoric Britain (Bishop and Lytwyn, 2007; Bowden, 1984; Brown and Tuzin 1983; Conklin, 2001; de Castro, 1992; Forsyth, 1983; Goldman, 1999; Petersen and Crock, 2007; Sanday, 1986; Zegwaard, 1959). Caves as liminal spaces (Barnatt and Edmonds, 2002; Leach, 2008) may have presented especially appropriate locations for such non-normative behaviours, recalling the evidence for modified human remains from Gough's Cave. But in the end the ulna is, at present, an isolated find, and can provide only limited, if intriguing, insights. 


\section{ACKNOWLEDGEMENTS}

The authors would like to thank the Trustees of the Torquay Museum for allowing sampling for AMS dating. Thanks also to Ian Cartwright for photography and to Peter Ditchfield for running the stable isotope measurements. We are grateful to two anonymous reviewers and the editor for comments on an earlier version of the manuscript. Funding for the radiocarbon date was provided by a Leverhulme Research Grant (F/08 735/E) to RJS. SB’s involvement was supported by the AHOB project (Ancient Human Occupation of Britain), funded by the Leverhulme Trust and the Calleva Foundation.

\section{REFERENCES}

Andrews, P, and Cook, J. 1985. Natural modifications to bones in a temperate setting. Man (N.S.) 20: $675-691$.

Andrews, P, and Fernández-Jalvo, Y. 2003. Cannibalism in Britain: taphonomy of the Creswellian (Pleistocene) faunal and human remains from Gough's Cave (Somerset, England). Bulletin of Natural History Museum London (Geology) 58 (suppl): 59-81.

Arens, W. 1979. The Man-Eating Myth: Anthropology and Anthropophagy. Oxford University Press: Oxford.

Auboire, G. 1991. Les restes humains Mésolithiques de Noyen-sur-Seine (Seine-et-Marne, France). L'Anthropologie 95: 229-236.

Bahn, P. 1990. Eating people Is wrong. Nature 348: 395.

Barnatt, J, and Edmonds, MR. 2002. Places apart? Caves and monuments in Neolithic and earlier Bronze Age Britain. Cambridge Archaeological Journal 12: 113-129.

Barrett, JC. 1994. Fragments from Antiquity. Blackwell: Oxford.

Behrensmeyer, A, Gordon, K, and Yanagi, G. 1986. Trampling as a cause of bone surface damage and pseudo-cut marks. Nature 319: 768-771.

Bello, SM, Parfitt, SA, and Stringer, C. 2009. Quantitative micromorphological analyses of cut marks produced by ancient and modern handaxes. Journal of Archaeological Science 36: 18691880 .

Bello, SM, Parfitt, SA, and Stringer, C. 2011. Earliest directly-dated human skull-cups. Plos ONE 6: e17026.

Bello, SM, and Soligo, C. 2008. A new method for the quantitative analysis of cutmark 
micromorphology. Journal of Archaeological Science 35: 1542-1552.

Bermúdez de Castro, JM, Bromage, TG, and Fernández Jalvo, Y. 1988. Buccal striations on fossil human anterior teeth: evidence of handedness in the middle and early Upper Pleistocene. Journal of Human Evolution 17: 403-412.

Bishop, CA, and Lytwyn, VP. 2007. "Barbarism and ardour of war from the tenderest years": Cree-Inuit warfare in the Hudson Bay region. In: RJ Chacon and RG Mendoza (eds.), North American Indigenous Warfare and Ritual Violence: pp. 30-57. University of Arizona Press: Tucson.

Blumenschine, RJ, and Selvaggio, MM. 1988. Percussion marks on bone surfaces as a new diagnostic of hominid behaviour. Nature 333: 763-765.

Bocherens, H, Fogel, ML, Tuross, N, and Zeder, M. 1995. Trophic structure and climatic information from isotopic signatures in Pleistocene cave fauna of southern England. Journal of Archaeological Science 22: 327-340.

Boulestin, B. 1999. Approche Taphonomique des Restes Humaines. Le Cas des Mésolithiques de la Grotte des Perrats et le Problème du Cannibalisme en Préhistoire Récente Européenne. BAR International Series 776: Oxford:

Boulestin, B, and Gomez de Soto, J. 1995. Le cannibalisme au Néolithique: réalité et sens. In: JM Large (ed.), "La Mort". Passé, Présent, Conditionel: pp. 59-68. Groupe Vendéen d'Etudes Préhistoriques: La Roche-sur-Yon.

Boulestin, B, Zeeb-Lanz, A, Jeunesse, C, Haack, F, Arbogast, R-M, and Denaire, A. 2009. Mass cannibalism in the Linear Pottery Culture at Herxheim (Palatinate, Germany). Antiquity 83: 968982.

Bowden, R. 1984. Maori cannibalism: an interpretation. Oceania 55: 81-99.

Brock, F, Bronk Ramsey, C, and Higham, TFG. 2007. Quality assurance of ultrafiltered bone dating. Radiocarbon 49: 189-192.

Brock, F, Higham, TFG, Ditchfield, P, and Bronk Ramsey, C. 2010. Current pretreatment methods for AMS radiocarbon dating at the Oxford Radiocarbon Accelerator Unit (ORAU). Radiocarbon 52: 102-112.

Bromage, TG, and Boyde, A. 1984. Microscopic criteria for the determination of directionality of cutmarks on bone. American Journal of Physical Anthropology 65: 359-366.

Bronk Ramsey, C, Higham, T, Bowles, A, and Hedges, R. 2004a. Improvements to the pretreatment of bone at Oxford. Radiocarbon 46: 155-163.

Bronk Ramsey, C, Higham, TFG, and Leach, P. 2004b. Towards high precision AMS: progress 
and limitations. Radiocarbon 46: 17-24.

Brothwell, DR. 1961. Cannibalism in early Britain. Antiquity 35: 304-307.

Brown, P, and Tuzin, DF (eds.). 1983. The Ethnography of Cannibalism. Society for Psychological Anthropology: Washington, D.C..

Campbell, JB. 1977. The Upper Palaeolithic of Britain. Clarendon Press: Oxford.

Campbell, JB, and Sampson, GG. 1971. A new analysis of Kent's Cavern, Devonshire, England. University of Oregon Anthropological Papers 3: 1-7, 40.

Carbonell, E, Cáceres, I, Lozano, M, Saladié, P, Rosell, J, Lorenzo, C, Vallverdú, J, Huguet, R, Canals, A, and Bermúdez de Castro, JM. 2010. Cultural cannibalism as a paleoeconomic system in the European Lower Pleistocene: the case of level TD6 of Gran Dolina (Sierra de Atapuerca, Burgos, Spain). Current Anthropology 51: 539-549.

Cauwe, N. 1998. La Grotte Margaux à Anseremme-Dinant. University of Liège, Études et Recherches Archéologiques Eraul 59: Liège.

Chaix, L, Simon, C, and Voruz, J-L. 1991. Découpe de boucherie sur des ossements humains dans le Néolithique ancien de la grotte du Gardon (Ain), Méthodes d'étude des sépultures: pp. 147-149. CNRS: Paris.

Chamberlain, A. 1996. More dating evidence for human remains in British caves. Antiquity 70: 950-953.

Chandler, B, Schulting, RJ, and Higham, TFG. 2009. Cannibals in the Cavern? New research on the black mould layer of Kent's Cavern. Transactions and Proceedings of the Torquay Natural History Society 24: 164-175.

Conklin, BA. 2001. Consuming Grief: Compassionate Cannibalism in an Amazonian Society. University of Texas Press: Austin.

Cook, GT, Bonsall, C, Hedges, REM, McSweeney, K, Boronean, V, and Pettitt, PB. 2001. A freshwater diet-derived 14C reservoir effect at the stone age sites in the Iron Gate Gorge. Radiocarbon 43: 453-460.

Cook, J. 1986. Marked human bones from Gough's Cave, Somerset. Proceedings of the University of Bristol Spelaeological Society 17: 275-285.

Cook, J. 1991. Preliminary report on marked human bones from the 1986-1987 excavations at Gough's Cave, Somerset, England. In: N Barton, AJ Roberts and DA Roe (eds.), The Late Glacial in North-West Europe: Human Adaptation and Environmental Change at the End of the Pleistocene: pp. 160-168. Council for British Archaeology, Research Report 77: London. 
De Castro, EV. 1992. From the Enemy's Point of View: Humanity and Divinity in an Amazonian Society. University of Chicago Press: Chicago.

Degerbøhl, M. 1942. Knoglemateriale fra. Dyrholmen-bopladsen. In: T Mathiassen, M Degerbøhl and J Troels-Smith (eds.), Dyrholmen. En Stenalderboplads paa Djursland: pp. 77135. Det Kongelige Danske Videnskabernes Selskab, Arkæologisk-Kunsthistoriske Skrifter, Bind 1, Nr. 1: København.

DeNiro, MJ. 1985. Post-mortem preservation and alteration of in vivo bone collagen isotope ratios in relation to palaeodietary reconstruction. Nature 317: 806-809.

Domínguez-Rodrigo, M, de Juana, S, Galán, AB, and Rodríguez, M. 2009. A new protocol to differentiate trampling marks from butchery cut marks. Journal of Archaeological Science 36: 2643-2654.

Ducrocq, T, le Goff, I, and Valentin, F. 1996. La sépulture secondaire Mésolithique de la Chaussée-Tirancourt (Somme). Bulletin de la Société Préhistorique Française 93: 211-216.

Evans, C, and Hodder, I. 2006. A Woodland Archaeology. Neolithic Sites at Haddenham. Cambridge: McDonald Institute Monographs.

Fernández-Jalvo, Y, and Andrews, P. 2011. When humans chew bones. Journal of Human Evolution 60: 117-123.

Forsyth, DW. 1983. The beginnings of Brazilian anthropology: the Jesuits and Tupinamba cannibalism. Journal of Anthropological Research 39: 147-178.

Garrod, DAE. 1926. The Upper Palaeolithic Age in Britain. Clarendon Press: Oxford.

Goldman, LR (ed.) 1999. The Anthropology of Cannibalism. Bergin \& Garvey: Westport.

Gray, H. 1977. Gray's Anatomy. Bounty Books: New York.

Greenfield, HJ. 1999. The origins of metallurgy: distinguishing stone from metal cut-marks on bones from archaeological sites. Journal of Archaeological Science 26: 797-808.

Hedges, REM, Housley, RA, Bronk Ramsey, C, and van Klinken, GJ. 1991. Radiocarbon dates from the Oxford AMS system: Archaeometry datelist 13. Archaeometry 33: 279-296.

Hedges, REM, Housley, RA, Law, IA, and Bronk Ramsey, C. 1989. Radiocarbon dates from the Oxford AMS system: Archaeometry datelist 9. Archaeometry 31: 207-234.

Hedges, REM, Pettitt, PB, Bronk Ramsey, C, and van Klinken, GJ. 1996. Radiocarbon dates from the Oxford AMS system: Archaeometry datelist 22. Archaeometry 38: 391-415.

Heyworth, A, and Kidson, C. 1982. Sea-level changes in south west England and Wales. 
Proceedings of the Geologist's Association 93: 91-111.

Higham, T, Compton, T, Stringer, C, Jacobi, R, Shapiro, B, Trinkaus, E, Chandler, B, Gröning, F, Collins, C, Hillson, S, O’Higgins, P, FitzGerald, C, and Fagan, M. 2011. The earliest evidence for anatomically modern humans in northwestern Europe. Nature 479: 521-524.

Higham, TFG, Jacobi, RM, and Bronk Ramsey, C. 2006. AMS radiocarbon dating of ancient bone using ultrafiltration. Radiocarbon 48: 179-195.

Jacobi, RM, and Higham, TFG. 2009. The early Lateglacial re-colonization of Britain: new radiocarbon evidence from Gough's Cave, southwest England. Quaternary Science Review 28: 1895-1913.

Jacobi, RM, and Higham, TFG. 2010. The British earlier Upper Palaeolithic: settlement and chronology. In: N Ashton, SG Lewis and C Stringer (eds.), The Ancient Human Occupation of Britain: pp. 181-222. Elsevier: Amsterdam.

Jacobi, RM, Higham, TFG, and Bronk Ramsey, C. 2006. AMS radiocarbon dating of Middle and Upper Palaeolithic bone in the British Isles: improved reliability using ultrafiltration. Journal of Quaternary Science 21: 557-573.

Keen, DH. 1998. Kent's Cavern. In: S Campbell, CO Hunt, JD Scourse, DH Keen and N Stephens (eds.), Quaternary of South-West England: pp. 134-138. Joint Nature Conservation Committee and Chapman \& Hall: London

Knüsel, CJ. 2005. The physical evidence of warfare - subtle stigmata? In: M Parker Pearson and IJN Thorpe (eds.), Warfare, Violence and Slavery in Prehistory: pp. 49-65. British Archaeological Reports, International Series 1374: Oxford.

Knüsel, CJ, and Outram, AK. 2006. Fragmentation of the body: comestibles, compost, or customary rite? In: R Gowland and C Knüsel (eds.), The Social Archaeology of Funerary Remains: pp. 253-278. Oxford: Oxbow.

Leach, S. 2008. Odd one out? Earlier Neolithic deposition of human remains in caves and rock shelters in the Yorkshire Dales. In: E Murphy (ed.), Deviant Burial in the Archaeological Record: pp. 35-56. Oxbow: Oxford.

Lundberg, J, and McFarlane, DA. 2007. Pleistocene depositional history in a periglacial terrane: A 500ka record from Kents Cavern, Devon, United Kingdom. Geosphere 3: 199-219.

Lundberg, J, and McFarlane, DA. 2008. Kent's Cavern. A Field Guide to the Natural History. William Pengelly Cave Studies Trust: Buckfastleigh.

MacEnery, J. 1859. Cavern researches, or Discoveries of organic remains, and of British and Roman reliques, in the caves of Kents Hole, Anstis Cove, Chudleigh, and Berry Head. Simpkin, Marshall, and Co: London. 
Marshall, P, and van der Plicht, J. 2005. Dating, in R.J. Schulting '...pursuing a rabbit in Burrington Combe': New research on the Early Mesolithic burial cave of Aveline's Hole. Proceedings of the University of Bristol Spelaeological Society 23: 226-233.

McFarlane, DA, and Lundberg, J. 2005. The 19th century excavation of Kent's Cavern, England. Journal of Cave and Karst Studies 67: 39-47.

McKinley, JI. 2008. The human remains. In: RJ Mercer and F Healy (eds.), Hambledon Hill, Dorset, England. Excavation and survey of a Neolithic monument complex and its surrounding landscape: pp. 477-521. English Heritage Archaeological Reports: London.

Meiklejohn, C, Chamberlain, AT, and Schulting, RJ. 2011. Radiocarbon dating of Mesolithic human remains in Great Britain. Mesolithic Miscellany 21: 20-58.

Murphy, E. 2003. Funerary processing of the dead in prehistoric Ireland. Archaeology Ireland 17: 13-15.

Nuñez, M, and Lidén, K. 1997. Taking the 5000 year old "Jettböle skeletons" out of the closet: a palaeo-medical examination of human remains from the Åland (Ahvenanmaa) Islands. International Journal of Circumpolar Health 56: 30-39.

Orschiedt, J, and Haidle, MN. 2007. The LBK enclosure at Herxheim: theatre of war or ritual centre? References from osetoarchaeological investigations. In: T Pollard and I Banks (eds.), War and Sacrifice: pp. 153-167. Brill: Leiden.

Orschiedt, J, and Haidle, MN. 2012. Violence against the living, violence against the dead on the human remains from Herxheim, Germany. Evidence of a crisis and mass cannibalism? In: RJ Schulting and L Fibiger (eds.), Sticks, Stone and Broken Bones: Neolithic Violence in a European Context: pp. 121-137. Oxford University Press: Oxford.

Outram, AK. 2002. Bone fracture and within-bone nutrients: an experimentally based method for investigating levels of marrow extraction. In: P Miracle and N Milner (eds.), Consuming Passions and Patterns of Consumption: pp. 51-63. McDonald Institute for Archaeology: Cambridge.

Pengelly, W. 1863-1868. Kent's Cavern Exploration Journal 1863-1880, Vol. 1, 4 Nov 1863 - 17 Dec 1868. Unpublished manuscript AR4143, on file at the Torquay Museum, Torquay.

Pengelly, W. 1868. The literature of Kent's Cavern, Torquay, prior to 1859. Transactions of the Devonshire Association 2: 462-522.

Pengelly, W. 1885. The literature of Kent's Cavern (Part V). Transactions of the Devonshire Association 16: 189-434.

Petersen, JB, and Crock, JG. 2007. “Handsome Death”: the taking, veneration, and consumption 
of human remains in the insular Caribbean and Greater Amazonia. In: RJ Chacon and DH Dye (eds.), The Taking and Displaying of Human Body Parts as Trophies by Amerindians: pp. 547574. Springer: New York.

Pickering, MP. 1989. Food for thought: an alternative to 'cannibalism in the Neolithic'. Australian Archaeology 28: 35-39.

Pickering, MP. 1999. Consuming doubts: What people ate? Or what some people swallowed? In: LR Goldman (ed.), The Anthropology of Cannibalism: pp. 51-74. Westport: Bergin and Garvey.

Pickering, TR, and Egeland, CP. 2006. Experimental patterns of hammerstone percussion damage on bones: implications for inferences of carcass processing by humans. Journal of Archaeological Science 33: 459-469.

Pickering, TR, and Hensley-Marschand, B. 2008. Cutmarks and hominid handedness. Journal of Archaeological Science 35: 310-315.

Reimer, PJ, Baillie, MGL, Bard, E, Bayliss, A, Beck, JW, Blackwell, PG, Bronk Ramsey, C, Buck, CE, Burr, GS, Edwards, RL, Friedrich, M, Grootes, PM, Guilderson, TP, Hajdas, I, Heaton, TJ, Hogg, AG, Hughen, KA, Kaiser, KF, Kromer, B, McCormac, FG, Manning, SW, Reimer, RW, Richards, DA, Southon, JR, Talamo, S, Turney, CSM, van der Plicht, J, and Weyhenmeyer, CE. 2009. IntCal09 and Marine09 radiocarbon age calibration curves, 0-50,000 years cal BP. Radiocarbon 51: 1111-1150.

Richards, MP, and Hedges, REM. 2003. Bone collagen $\delta^{13} \mathrm{C}$ and $\delta^{15} \mathrm{~N}$ values of fauna from Northwest Europe reflect palaeoclimatic variation over the last 40,000 years. Palaeogeography, Palaeoclimatology, Palaeoecology 193: 261-267.

Sanday, PR. 1986. Divine Hunger: Cannibalism as a Cultural System. Cambridge University Press: Cambridge.

Schulting, RJ. 2005. '...pursuing a rabbit in Burrington Combe': New research on the Early Mesolithic burial cave of Aveline's Hole. Proceedings of the University of Bristol Spelaeological Society 23: 171-265.

Schulting, RJ. 2009. Worm's Head, Caldey Island (south Wales, UK) and the question of Mesolithic territories. In: SB McCartan, RJ Schulting, G Warren and PC Woodman (eds.), Mesolithic Horizons: pp. 355-361. Oxbow: Oxford.

Schulting, RJ, and Richards, MP. 2002. Finding the coastal Mesolithic in southwest Britain: AMS dates and stable isotope results on human remains from Caldey Island, Pembrokeshire, South Wales. Antiquity 76: 1011-1025.

Schulting, RJ, and Wysocki, M. 2005. "In this chambered tumulus were found cleft skulls...": an assessment of the evidence for cranial trauma in the British Neolithic. Proceedings of the Prehistoric Society 71: 107-138. 
Shipman, P. 1981. Applications of scanning electron microscopy to taphonomic problems. Annals of the New York Academy of Sciences 276: 357-385.

Shipman, P, and Rose, J. 1983. Early hominid hunting, butchering, and carcass processing behaviors: approaches to the fossil record. Journal of Anthropological Archaeology 2: 57-98.

Silvester, RJ. 1986. The later prehistoric and Roman material from Kent's Cavern, Torquay. Proceedings of the Devon Archaeological Society 44: 9-38.

Smith, MJ, and Brickley, MB. 2004. Analysis and interpretation of flint toolmarks found on bones from West Tump long barrow, Gloucestershire. International Journal of Human Osteology 14: 18-33.

Smits, L, and van der Plicht, H. 2009. Mesolithic and Neolithic human remains in the Netherlands: physical anthropological and stable isotope investigations. Journal of Archaeology in the Low Countries 1: 55-85. http://dpc.uba.uva.nl/jalc/01/nr01/a04.

Taylor, T. 2003. The Buried Soul. Fourth Estate: London.

Thomas, J. 1999. Understanding the Neolithic. Routledge: London.

Toussaint, M. 2011. Intentional cutmarks on an Early Mesolithic numan calvaria from Margaux Cave (Dinant, Belgium). American Journal of Physical Anthropology 144: 100-107.

Turner, CG, and Turner, JA. 1999. Man Corn. Cannibalism and Violence in the Prehistoric American Southwest. University of Utah Press: Salt Lake City.

Tuross, N. 2003. Letter on file at the Torquay Museum, Torquay, Devon.

Villa, P. 1992. Cannibalism in prehistoric Europe. Evolutionary Anthropology 1: 93-104.

Villa, P, Courtin, J, Helmer, D, Shipman, P, Bouville, C, and Mahieu, E. 1986. Un cas de cannibalisme au Néolithique. Boucherie et rejet des restes humaines et animaux dans la grotte de Fontbrégoua (Salernes, Var). Gallia-Préhistoire 29: 143-171.

Villa, P, and Mahieu, È. 1991. Breakage patterns of human long bones. Journal of Human Evolution 21: 27-48.

Ward, GK, and Wilson, SR. 1978. Procedures for comparing and combining radiocarbon age determinations: a critique. Archaeometry 20: 19-31.

Warren, CN, and Rose, S. 1994. William Pengelly's techniques of archaeological excavation. Torquay Natural History Society: Torquay.

Wheatley, BP. 2007. Perimortem or postmortem bone fractures? An experimental study of 
fracture patterns in deer femora. Journal of Forensic Sciences 53: 69-72.

White, TD. 1992. Prehistoric Cannibalism at Mancos 5Mtumr-2346. Princeton University Press: Princeton.

Whitley, J. 2002. Too many ancestors. Antiquity 76: 119-126.

Zegwaard, GA. 1959. Headhunting practices of the Asmat of Netherlands New Guinea. American Anthropologist 61: 1020-1041. 


\begin{tabular}{|c|c|c|c|c|c|c|c|c|c|}
\hline Sample & Context & Element & Lab no. & ${ }^{14} \mathrm{C} B P$ & \pm & \multicolumn{2}{|c|}{ cal BC/AD 95\% } & $\delta^{13} \mathrm{C}$ & Reference \\
\hline 0.309 & Vestibule & maxilla & OxA-1621 & 30900 & 900 & 35906 & 31633 & - & Hedges et al., 1989 \\
\hline 0.309 & $\begin{array}{l}\text { Vestibule } \\
\text { Sloping }\end{array}$ & maxilla & & \multicolumn{2}{|c|}{ 37-35 ka BP } & \multicolumn{2}{|c|}{$44.2-41.5$ cal BP } & & $\begin{array}{l}\text { Higham et al., } 2011 \\
\text { this paper; Chandler }\end{array}$ \\
\hline A6473 & Chamber & R ulna & OxA-20588 & 8185 & 38 & 7314 & 7075 & -19.7 & et al., 2009 \\
\hline A2540 & Vestibule & maxilla & OxA-1786 & 8070 & 90 & 7308 & 6698 & - & Hedges et al., 1989 \\
\hline A2540 & Vestibule & maxilla & OxA-23812 & 8270 & 45 & 7478 & 7145 & -19.3 & this paper \\
\hline A6645 & Sloping & & & & & & & & \\
\hline & Chamber & L ulna & OxA-23809 & 5053 & 29 & 3952 & 3783 & -20.7 & this paper \\
\hline A5885 & & mand tooth & OS-36644 & 5020 & 45 & 3947 & 3708 & -18.2 & Tuross, 2003 \\
\hline & & cranium & OxA-1787 & 3560 & 70 & 2131 & 1695 & & Hedges et al., 1989 \\
\hline A5884 & & mand tooth & OS-36643 & 3460 & 40 & 1890 & 1684 & -17.8 & Tuross, 2003 \\
\hline & Sloping & & & & & & & & \\
\hline A6643 & Chamber & $\mathrm{R}$ radius & OxA-23810 & 3008 & 26 & 1378 & 1131 & -21.8 & this paper \\
\hline KC 5 & & ulna & OxA-13132 & 1520 & 90 & $\mathrm{AD}$ & $41-666$ & -19.6 & this paper \\
\hline KC 6 & & mandible & OxA-11783* & 570 & 24 & $\mathrm{AD} 1$ & $9-1419$ & -17.7 & this paper \\
\hline
\end{tabular}

Table 1. Radiocarbon dated human remains from Kent's Cavern. NB: OxA-11783 is subject to possible ultrafilter contamination (Brock et al., 2007; 2010), but should be broadly correct. OxA1621 is considered a significant underestimate of the real age of this specimen, which Higham et al. (2011) have recently suggested is better placed at ca. 44.2-41.5 ka cal BP. Calibrated with OxCal v4.1, using IntCal09 (Reimer et al., 2009). 


\section{Figure captions}

Figure 1. Map showing location of Kent's Cavern and sites with Late Upper Paleolithic and Mesolithic human remains in southwest Britain. The coastline at ca. $8000{ }^{14} \mathrm{C}$ years BP (ca. 7000-6850 cal BC) would have been about -20m lower than at present.

Figure 2. Plan of Kent's Cavern; the ulna was found in the 'Sloping Chamber'. From survey by Chris Procter.

Figure 3. Right proximal adult ulna from Kent's Cavern (Torquay Museum A6473). Photo: R. Schulting.

Figure 4. Proximal end of ulna showing series of cut-marks; scale bar $1 \mathrm{~cm}$. Photo: R. Schulting.

Figure 5. First cluster of cut-marks on the Kent's Cavern ulna, Alicona InfiniteFocus optical surface measurement system, 2.5x magnification; scale bar $1 \mathrm{~cm}$. Image: S. Bello.

Figure 6. Impact point on Kent's Cavern ulna, with Alicona InfiniteFocus optical surface measurement system, 2.5x magnification; scale bar $1 \mathrm{~cm}$. Image: S. Bello.

Figure 7. Smooth fracture surfaces on the Kent’s Cavern ulna. Photo: R. Schulting.

Figure 8. Human maxilla fragment from Kent's Cavern, directly dated to the Mesolithic. Photo: R. Schulting.

Figure 9. Red deer humerus (P8299) from the black mould layer in the Sloping Chamber, exhibiting a spiral fracture. Dated to $12922-12046$ cal BC (95\% probability). Photo: R. Schulting.

Figure 10. Locations of cut-marks (red lines) and impact points (black arrows: percussion damage; white arrows: anvil scars) on the Kent's Cavern and Gough's Cave ulnae. Image: S. Bello.

Figure 11. Percussion pits on Gough’s Cave ulna. Photo: S. Bello. 